\title{
PREDICTING THE IMPACT OF A FCC TURBO EXPANDER ON PETROLEUM REFINERIES
}

\author{
N. E. G. Fermoselli \\ Chemical Engineer \\ Av. Carlos de Araújo \\ Gobbi, apto.53B, \\ Vl. S. Bento, \\ Campinas, SP, Brazil, \\ CEP: $13034-670$ \\ noemiafer@yahoo.com
}

\begin{abstract}
Implementing a turbo expander connected to a fluid catalytic cracking (FCC) unit in order to produce power from flue gas has already become a common practice in oil refineries worldwide. Despite of recovering energy which used to be wasted in an orifice chamber, the implementation of expander and its skids still requires high investment, which often begins with a third-stage cyclones installation to enhance flue gas cleanness. Moreover, machine and also pipes need to be made with special materials in order to resist high temperatures and erosion. Hence, there are some items to be checked before start up a turbo expander to ensure the return on investment will reach expectations, keeping in mind that its ability to extract energy from flue gas changes widely depending on FCC operational conditions. Then, the aim of this paper is to provide the analysis of one stage turbo expander which is fed with flue gas from partial combustion FCC unit and installed with isolation valves, highlighting some points which deserve special attention before start up this type of machine. It brings together some approaches to provide valuable information about a turbo expander, particularly when it is not running yet, including the results to a hypothetical case and the sequence of calculus that can be done without using any special software applied for: - To estimate real energy generation through the turbo expander as a function of FCC feed; $\bullet$ To check the leaks effect; $\bullet$ To predict the impact of turbo expander on carbon monoxide boiler, due to a fall in temperature of the expanded flue gas; - To calculate the appropriate amount of extra supplementary gas required to be burned in the flue gas boiler in order to keep the production of steam stable; $\bullet$ To analyze the moisture of the flue gas so that it may predicts condensation when hot gas comes into contact with the cold duct, after opening isolation valves; • And finally, how turbo expanders fit in cleaning development mechanism to get certified carbon credits.
\end{abstract}

Keywords: turbo expander, FCC, power recovery

\section{INTRODUCTION}

Implementing a turbo expander connected to a fluid catalytic cracking (FCC) unit in order to produce power from flue gas has already become a common practice in oil refineries worldwide. The main machine responsible for this process is also called FCC Power Recovery Expander. Figure 1 shows a typical system of one stage turbo expander fed with flue gas from partial combustion FCC unit and installed with isolation valves.

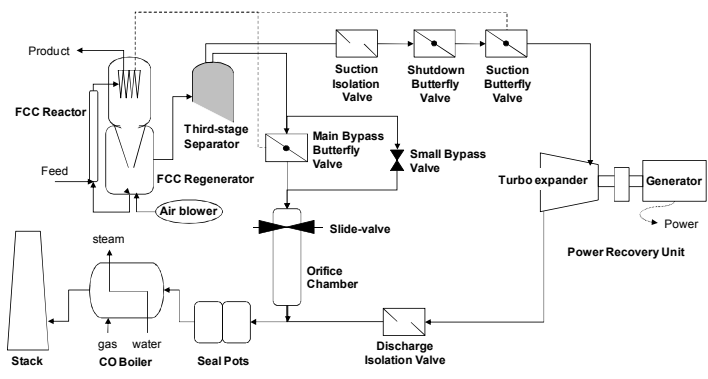

Figure 1. Typical FCC power recovery arrangement involving partial combustion and isolation valves.

Despite of recovering energy which used to be wasted in an orifice chamber, the implementation of expander and its skids still requires high investment, which often begins with a third-stage cyclones installation to enhance flue gas cleanness. The third separator removes excess of FCC catalyst, which could damage the rotating blades. Moreover, machine and also pipes need to be made with special materials in order to resist to high temperatures and erosion. Hence, there are some items to be checked before start up a turbo expander to ensure the return on investment will reach expectations, keeping in mind that its ability to extract energy from the flue gas changes widely depending on FCC operational conditions.

Then, this paper brings together different approaches to provide valuable information about a turbo expander, particularly when it is not running yet, including the sequence of calculus that can be done without using any special software and the results to a hypothetical case.

Typical gas compositions and molecular weights are given in Tab. 1.

Table 1. Mol fraction of flue gas and natural gas.

\begin{tabular}{|c|c|c|c|}
\hline Flue Gas: i & $\begin{array}{c}\text { Mol } \\
\text { Fraction }\end{array}$ & $\begin{array}{c}\text { Natural } \\
\text { Gas: } \mathrm{i}\end{array}$ & $\begin{array}{c}\text { Mol } \\
\text { Fraction }\end{array}$ \\
\hline $\mathrm{O}_{2}$ & 0.01 & $\mathrm{~N}_{2}$ & 0.01 \\
\hline $\mathrm{N}_{2}$ & 0.67 & $\mathrm{CH}_{4}$ & 0.88 \\
\hline $\mathrm{H}_{2} \mathrm{O}$ & 0.14 & $\mathrm{CO}_{2}$ & 0.01 \\
\hline $\mathrm{CO}$ & 0.06 & $\mathrm{C}_{2} \mathrm{H}_{6}$ & 0.06 \\
\hline $\mathrm{CO}_{2}$ & 0.11 & $\mathrm{C}_{3} \mathrm{H}_{8}$ & 0.02 \\
\hline $\mathrm{SO}_{2}$ & 0.01 & $\mathrm{C}_{4} \mathrm{H}_{10}$ & 0.01 \\
\hline $\mathrm{CH}_{4}$ & 0 & $\mathrm{C}_{5} \mathrm{H}_{12}$ & 0.01 \\
\hline $\mathrm{M}(\mathrm{kg} / \mathrm{kmol})$ & 28.8 & $\mathrm{M}(\mathrm{kg} / \mathrm{kmol})$ & 18.8 \\
\hline
\end{tabular}




\section{CORRELATION BETWEEN FCC FEED AND EXPANDER POWER OUTPUT}

\section{Power versus FCC Feed}

The capacity of the expander chosen in this case is $15 \mathrm{MW}$, which means that the machine is able to produce this amount of power, but unfortunately it will not necessarily happen. Though the manufacturer supplies a graph with several parameters, refineries do not reach the range of some of them, so it is possible to simplify that graph and add some refinery data in order to simulate the real behavior of that specific turbo expander about power generation.

The machine efficiency is commonly informed by the manufacturer and it is usually close to $80 \%$, efficiency that will be used in this case. It is also considered some efficiency loss if operational temperature is lower than $650^{\circ} \mathrm{C}$, as shown in Tab. 2 .

Table 2. Power loss at low operational temperatures.

\begin{tabular}{|c|c|}
\hline Condition & $\begin{array}{c}\text { Loss } \\
(\mathrm{MW})\end{array}$ \\
\hline If $630^{\circ} \mathrm{C}<$ operational temperature $<650^{\circ} \mathrm{C}$ & -0.4 \\
\hline For operational temperature $<630^{\circ} \mathrm{C}$ & -0.8 \\
\hline
\end{tabular}

The first curve of Fig. 2 simplifies a typical manufacturer's graph to a line (normal project operation).

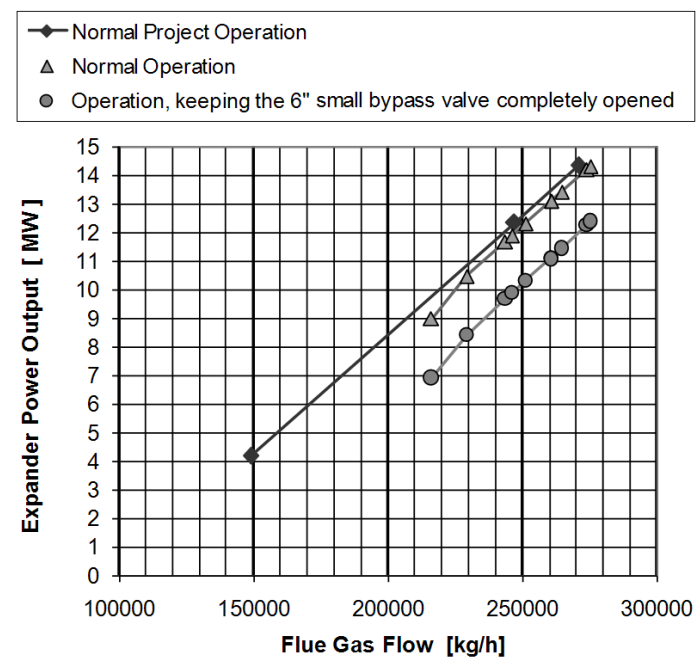

Figure 2. Estimation of expander power output versus flue gas flow.

The " $X$ " axis of Fig. 2 corresponds to the flue gas flow that comes from the third-stage separator and cross turbo expander, while " $Y$ " axis provides the energy generated by the power recovery unit.

The second curve (normal operation) is built with a hypothetical average of annual data, including typical variation in pressures and temperatures. Data when the FCC unit does not work properly should be excluded. If the project was well done, the second curve will be close to the project curve, as happens in Fig. 2. Anyway, if the flue gas flow is substituted in the " $X$ " axis by FCC feed, the difference between the curves behavior stands out, as shown in Fig. 3.

It is interesting to note that the curve Power vs. FCC feed presents a third degree equation trend line with a satisfactory coefficient of determination. The lower is the FCC feed, the bigger is the variation in the flow of flue gas produced. In part, this variation is caused by the amount of air injected by the blower to burn the catalyst coke, depending on the severity of operation.

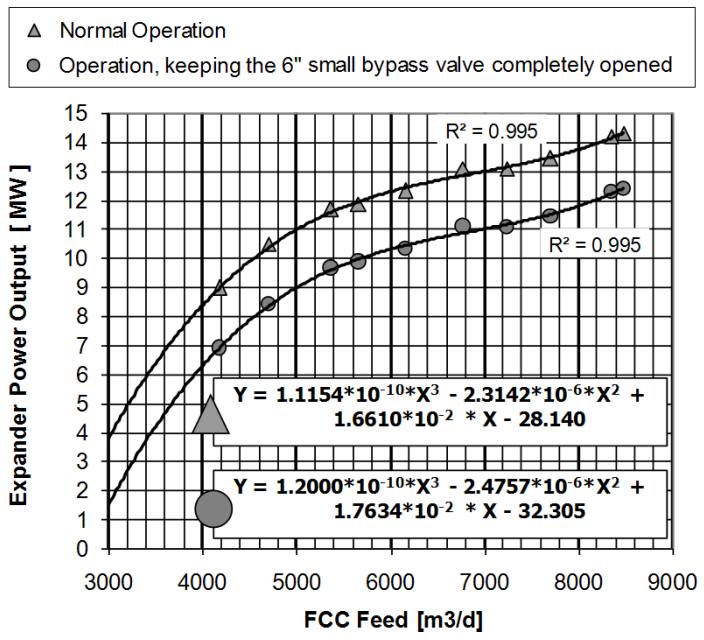

Figure 3. Estimation of expander power output versus FCC feed.

\section{Leaks Effect}

The last curves of Fig. 2 and Fig. 3, represented by circular dots, show the maximum loss of energy that may occurs if it is necessary to keep the "small bypass valve" completely opened (see Fig. 1). In this case, it was supposed a 6 inch size valve. This small bypass might provide heat for the orifice chamber to avoid acid condensation at low temperature, even if the "main bypass butterfly valve" is completely closed. Then Fig. 3 gives also the flow that would divert from expander through the small bypass and it is possible to obtain from both figures the energy loss due to this diversion.

To calculate this flow through the "small bypass valve", it was considered critical flow or sonic speed, which does not depend on upstream pressure because it is higher than the double of downstream pressure. The equations were adapted from API 520 (2000):

$$
\begin{gathered}
\mathrm{A}(\mathrm{mm} 2)=\left(13160^{*} \mathrm{~W}_{\mathrm{G}} *\left(\mathrm{~T}^{*} \mathrm{Z} / \mathrm{M}_{\mathrm{G}}\right)^{\wedge}(1 / 2)\right) / \\
\left(\mathrm{CC}^{*} \mathrm{Kd}^{*} \mathrm{PP} \mathrm{Kb}^{*} \mathrm{Kc}\right) \\
\mathrm{CC}=520^{*}\left(\mathrm{k}^{*}(2 /(\mathrm{k}+1))^{\wedge}((\mathrm{k}+1) /(\mathrm{k}-1))\right)^{\wedge}(1 / 2)
\end{gathered}
$$


where:

A effective area (obtained from the size of "small bypass valve"), $\mathrm{mm} 2$

$\mathrm{W}_{\mathbf{G}}$ mass flow of flue gas (the desired value), $\mathrm{kg} / \mathrm{h}$

$\mathrm{T}$ operational temperature, $\mathrm{K}$

$\mathrm{Z}$ gas compressibility factor, dimensionless; value $=1$ (low pressure and high temperature)

$\mathrm{M}_{\mathbf{G}} \quad$ flue gas molecular weight, $\mathrm{kg} / \mathrm{kmol}$

$\mathrm{K} \quad=\mathrm{cp} / \mathrm{cv}=($ heat capacity at constant pressure $) /$ (heat capacity at constant volume), dimensionless; in this case $=1.3$

Kd effective coefficient of discharge, dimensionless; in this case $=0.975$

PP upstream relieving pressure (approximated to: "absolute operational pressure - backpressure" because overpressure is zero), $\mathrm{kPa}$

$\mathrm{Kb}$ capacity correction factor due to backpressure, dimensionless; value $=1$ (it is not a balanced PSV)

Kc combination correction factor; dimensionless; value $=1$ (there is no rupture disc)

Even if after start-up it is checked that the "small bypass valve" could stay closed, it turns out that significant valve leakages would cause similar effect on energy losses. Consequently, if the power produced is much less than expected, leaks should be investigated to enhance expander operation. A way of confirming these leaks is using radiation to obtain pulse speed in each duct passage.

\section{IMPACT OF TURBO EXPANDER ON FLUE GAS BOILER (CO BOILER)}

Due to a fall in temperature of the expanded flue gas, there is an impact of turbo expander on flue gas boiler, also called carbon monoxide boiler, which is downstream (see Fig. 1). The flue gas is burned inside $\mathrm{CO}$ boiler and the heat vaporizes the water, producing high pressure steam. This heat comes from the temperature (sensible heat) and from the combustion itself. Because the flue gas is a poor gas, with low percentage of components that really burn, the temperature decreasing has an important impact on this case. It is possible to estimate the reduction in the high-pressure steam production of boiler, provoked for the expander start-up and calculate the additional amount of natural gas that would be burnt in the boiler in order to compensate the loss of sensible heat. Table 3 completes data from Tab. 1.

Table 3. Hypothetical process variables.

\begin{tabular}{|c|c|}
\hline Hypothetical Process Variables & Value \\
\hline FCC Feed $\left(\mathrm{m}^{3} / \mathrm{d}\right)$ & 8080 \\
\hline Mass Flow of Flue Gas to Expander $(\mathrm{kg} / \mathrm{h})$ & 273500 \\
\hline Inlet Expander Temperature $\left({ }^{\circ} \mathrm{C}\right)$ & 643 \\
\hline Inlet Expander Gauge Pressure $\left(\mathrm{kgf} / \mathrm{cm}^{2}\right)$ & 2.1 \\
\hline Outlet Expander Gauge Pressure $\left(\mathrm{kgf} / \mathrm{cm}^{2}\right)$ & 0.1 \\
\hline
\end{tabular}

\begin{tabular}{|c|c|}
\hline $\begin{array}{c}\text { Inlet Temperature of Water }\left({ }^{\circ} \mathrm{C}\right) \\
\text { CO Boiler }\end{array}$ & 176 \\
\hline $\begin{array}{c}\text { Outlet Temperature of Steam }\left({ }^{\circ} \mathrm{C}\right) \\
\text { CO Boiler }\end{array}$ & 483 \\
\hline $\begin{array}{c}\text { Inlet Gauge Pressure of Water }(\mathrm{kgf} / \mathrm{cm} 2) \\
\text { CO Boiler }\end{array}$ & 120 \\
\hline $\begin{array}{c}\text { Outlet Gauge Pressure of Steam (kgf } / \mathrm{cm} 2) \\
\text { CO Boiler }\end{array}$ & 90 \\
\hline $\begin{array}{c}\text { Inlet Boiler Temperature of Flue Gas } \\
\text { before Expander start-up }\left({ }^{\circ} \mathrm{C}\right)\end{array}$ & 594 \\
\hline
\end{tabular}

\section{Expansion Effect}

Initially, the outlet expander temperature is not available. Equations (3) to (5) solved together will provide the downstream temperature (Smith et al., 2000). Using the flow of Table 3, this would be the minimum outlet expander temperature.

$$
\begin{aligned}
& \Delta \mathrm{H}_{\text {mix }}=\Sigma \Delta \mathrm{Hi}=\Sigma\left\{\mathrm{fi}^{*} \operatorname{Int}(\mathrm{Cpi} . \mathrm{dT})\right\} \\
& \mathrm{Cp}_{\text {mix }}=\Sigma \mathrm{Cpi}=\Delta \mathrm{H} /(\mathrm{Tf}-\mathrm{To}) \\
& \mathrm{Tf}=\exp \left(\left((\mathrm{LN}(\mathrm{Pf} / \mathrm{Po})) /\left(\mathrm{Cp}_{\text {mix }} / \mathrm{RR}\right)\right)+\mathrm{LN}(\mathrm{To})\right)
\end{aligned}
$$

where:

$\mathrm{H}_{\text {mix }}$ gas enthalpy, $\mathrm{kJ} / \mathrm{kg}$

$\mathrm{Hi}$ enthalpy of component "i”, $\mathrm{kJ} / \mathrm{kg}$

$\mathrm{Cp}_{\text {mix }}$ specific heat of gas, $\mathrm{kJ} /(\mathrm{kg} . \mathrm{K})$

Cpi specific heat to component "i" as a function of To and $\mathrm{Tf}, \mathrm{kJ} /(\mathrm{kg} . \mathrm{K})$. See coefficients to calculate Cpi at Smith et al. (2000).

Tf final temperature (outlet expander temperature), $\mathrm{K}$. Tf is the desired value.

To initial temperature (inlet expander temperature in this case), $\mathrm{K}$

fi mass fraction

Pf absolute final pressure, bar

Po absolute initial pressure, bar

RR modified universal gas constant, $\mathrm{kJ} /(\mathrm{kg} . \mathrm{K})$; $8.314[\mathrm{~kJ} /(\mathrm{kmol} . \mathrm{K})] / \mathrm{M}_{\mathbf{G}}[\mathrm{kg} / \mathrm{kmol}]$

$\mathrm{M}_{\mathbf{G}} \quad$ flue gas molecular weight, $\mathrm{kg} / \mathrm{kmol}$

$\Delta \quad$ delta

$\Sigma$ sum

Int integral

exp exponential

LN natural logarithm

In this case, Outlet Expander Temperature result is equal to $469^{\circ} \mathrm{C}$. To check, it is calculated the power, using Eq. (6) adapted from Smith et al. (2000) or Eq. (7) (Dziewulski, 1994), keeping To $=643^{\circ} \mathrm{C}$ and $\mathrm{Tf}=469^{\circ} \mathrm{C}$.

$$
\begin{aligned}
\mathrm{IP}= & -\Delta \mathrm{H}_{\text {mix }} * \mathrm{~W}_{\mathbf{G}} * \eta_{\mathbf{E}} / 100 /\left(3.6^{*} 10^{6}\right) \\
\mathrm{IP}= & \left(\mathrm{Wkgs}_{\mathrm{G}} * 847.84 / \mathrm{M}_{\mathrm{G}} * \mathrm{To} / 102\right) *(\mathrm{k} /(\mathrm{k}-1))^{*} \eta_{\mathbf{E}} / 100 \\
& *\left(1-(\mathrm{Pf} / \mathrm{Po})^{\wedge}((\mathrm{k}-1) / \mathrm{k})\right) / 1000
\end{aligned}
$$

where: 
$\mathrm{W}_{\mathbf{G}}$ mass flow of flue gas to expander, $\mathrm{kg} / \mathrm{h}$ (in order to obtain the maximum value of energy production, it was not subtracted the possible flue gas flow that would divert to the "small bypass valve")

IP isentropic power, MW

$\eta_{\mathbf{E}} \quad$ expander efficiency, $\%$; in this case $=80$

$\mathrm{Wkgs}_{\mathbf{G}}$ mass flow of flue gas to expander, $\mathrm{kg} / \mathrm{s}$

It is established that $4 \%$ of this energy could be deduced because the process is not really isentropic. The final result (13.8 MW) will be close to the chart value from Fig. 2, as would be expected.

$\mathrm{Pw}=\mathrm{IP}^{*} 0.96-\mathrm{Pw}_{\text {loss }}$

where:

Pw expander power output, MW

$\mathrm{Pw}_{\text {loss }} \quad$ power loss, MW (see Tab. 2)

\section{Sensible Heat of Flue gas and Estimation of Steam Production Loss}

Once the minimum outlet expander temperature was calculated, it is possible to check the amount of heat lost before the boiler, keeping in mind that the temperature of flue gas that used to reach the boiler was already lower than the inlet expander temperature because of flue gas passage through orifice chamber. So, it is used the inlet boiler temperature of flue gas before expander start-up as the initial temperature and Eq. (9) provides what is the lost sensible heat due to the temperature fall from $594^{\circ} \mathrm{C}$ to $469^{\circ} \mathrm{C}$. Then, the lost heat allows estimating the amount of steam that would not be produced anymore due to expander start-up (Eq. (10)).

$\mathrm{Q}_{\text {loss }}=-\Delta \mathrm{H}_{\text {mix }} * \mathrm{~W}_{\mathbf{G}}$

$\mathrm{W}_{\mathrm{H} 2 \mathrm{O} \text { loss }}=\mathrm{Q}_{\text {loss }} / \Delta \mathrm{H}_{\mathrm{H} 2 \mathrm{O}}$

where:

Qloss lost heat in upstream boiler after expander start-up (sensible heat), $\mathrm{kJ} / \mathrm{h}$; see result in Tab. 4

$\mathrm{H}_{\text {mix }}$ gas enthalpy, $\mathrm{kJ} / \mathrm{kg}$; see Eq. (3) and Eq. (4), remembering that this time To $=$ Inlet Boiler Temperature of Flue Gas before Turbo expander start-up $\left(594^{\circ} \mathrm{C}\right)$, not Inlet Expander Temperature

$\mathrm{W}_{\mathbf{G}}$ mass flow of flue gas from expander to boiler (= mass flow of flue gas to expander), $\mathrm{kg} / \mathrm{h}$

$\mathrm{W}_{\text {H2O loss }}$ steam mass flow, $\mathrm{kg} / \mathrm{h}$; see result in Tab. 4

$\mathrm{H}_{\text {H2O }}$ enthalpy obtained from usual steam tables consulting Inlet Temperature of Water, Outlet Temperature of Steam, Inlet Gauge Pressure of Water and Outlet Gauge Pressure of Steam, $\mathrm{kJ} / \mathrm{kg}$;

$\Delta$ value $=2592.8$

\section{Confirmation of Boiler Production before Expander Start-up}

To see how much this value represents in percentage, it is needed to compare it with the normal production, which is usually a measurable data, or may be calculated as follows:
$\mathrm{Q}_{\text {Sensible FG }}$ or $\mathrm{Q}_{\text {Sensible SG }}$ or $\mathrm{Q}_{\text {Sensible Air }}=$ $-\Delta \mathrm{H}_{\text {mix }} * \mathrm{~W}_{\mathbf{G}}$
$\mathrm{PCSi}=-\Delta \mathrm{H}^{\circ} \mathrm{c}$
PCIi $=\left[\text { PCSi }-\mathrm{n}_{\mathbf{H} 2 \mathrm{O}} * \Delta \mathrm{H}_{\mathrm{mH} 2 \mathrm{O}}\right]^{*} \mathrm{xi}$
$\mathrm{PCI}_{\text {mix }}=\Sigma$ PCIi
$\mathrm{PCI}_{\text {mix }}(\mathrm{kJ} / \mathrm{kg})=\mathrm{PCI}_{\text {mix }}(\mathrm{kJ} / \mathrm{mol})^{*} 1000 / \mathrm{M}_{\mathbf{G}}$
$Q_{\text {Burn FG }}$ or $Q_{\text {Burn SG }}=$ $\mathrm{PCI}_{\text {mix }}(\mathrm{kJ} / \mathrm{kg}) * \eta_{\mathbf{B}} / 100 * \mathrm{~W}_{\mathbf{G}}$
$\mathrm{Q}_{\text {total }}=\mathrm{Q}_{\text {Burn FG }}+\mathrm{Q}_{\text {Burn SG }}+$ $\mathrm{Q}_{\text {Sensible FG }}+\mathrm{Q}_{\text {Sensible SG }}+\mathrm{Q}_{\text {Sensible Air }}$
$\mathrm{W}_{\text {H2Ototal }}=\mathrm{Q}_{\text {total }} / \Delta \mathrm{H}_{\mathrm{H} 2 \mathrm{O}}$

where:

FG flue gas

SG supplementary gas (natural gas)

Air air

$\mathrm{H}_{\text {mix }}$ enthalpy, kJ/kg; see Eq. (3) and Eq. (4), considering $\mathrm{Tf}=25^{\circ} \mathrm{C}(298.15 \mathrm{~K})$.

In this case: $\mathrm{To}_{\mathbf{F G}}=594^{\circ} \mathrm{C}$ (Inlet Boiler Temperature of Flue Gas before expander start-up); $\mathrm{To}_{\text {Air }}=35^{\circ} \mathrm{C} ; \mathrm{Q}$ sensible sG was irrelevant; $\mathrm{Cp}_{\text {Air }}$ was considered constant and equal to $0.24 \mathrm{~kJ} /(\mathrm{kg} . \mathrm{K})$.

$\mathrm{W}_{\mathbf{G}}$ mass flow of gas, $\mathrm{kg} / \mathrm{h} ; \mathrm{W}_{\text {Air }}=113800$

PCS superior calorific power of flue gas or supplementary gas, $\mathrm{kJ} / \mathrm{mol}$

PCI inferior calorific power of flue gas or supplementary gas, $\mathrm{kJ} / \mathrm{mol}$

$\Delta \mathrm{H}^{\circ} \mathrm{c}$ standard enthalpy of combustion, $\mathrm{kJ} / \mathrm{mol}$; tabled values given in Brasil (2004)

$\Delta \mathrm{H}_{\mathrm{mH2O}}$ enthalpy of water vaporization, $\mathrm{kJ} / \mathrm{mol}$; value $=43.9$

xi mol fraction

$\eta_{\mathbf{B}} \quad$ boiler efficiency, $\%$; in this case $=75$

$Q_{\text {sensible }}$ sensible heat, $\mathrm{kJ} / \mathrm{h}$

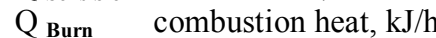

$\mathrm{Q}_{\text {total }}$ total boiler heat, $\mathrm{kJ} / \mathrm{h}$

$\mathrm{W}_{\text {H2Ototal }}$ boiler production before expander start-up, $\mathrm{kg} / \mathrm{h}$

$\mathrm{n}_{\mathrm{H} 2 \mathrm{O}}$ number of molecules of water formed according to combustion equations:

$\mathrm{CH}_{4(\mathrm{~g})}+2 \mathrm{O}_{2(\mathrm{~g})} \rightarrow 1 \mathrm{CO}_{2(\mathrm{~g})}+2 \mathrm{H}_{2} \mathrm{O}_{(\mathrm{L})}$

$\mathrm{C}_{2} \mathrm{H}_{6(\mathrm{~g})}+7 / 2 \mathrm{O}_{2(\mathrm{~g})} \rightarrow 2 \mathrm{CO}_{2(\mathrm{~g})}+3 \mathrm{H}_{2} \mathrm{O}_{(\mathrm{L})}$ 


$$
\begin{aligned}
& \mathrm{C}_{3} \mathrm{H}_{8(\mathrm{~g})}+5 \mathrm{O}_{2(\mathrm{~g})} \rightarrow 3 \mathrm{CO}_{2(\mathrm{~g})}+4 \mathrm{H}_{2} \mathrm{O}_{(\mathrm{L})} \\
& \mathrm{C}_{4} \mathrm{H}_{10(\mathrm{~g})}+13 / 2 \mathrm{O}_{2(\mathrm{~g})} \rightarrow 4 \mathrm{CO}_{2(\mathrm{~g})}+5 \mathrm{H}_{2} \mathrm{O}_{(\mathbf{L})} \\
& \mathrm{C}_{5} \mathrm{H}_{12(\mathrm{~g})}+8 \mathrm{O}_{2(\mathrm{~g})} \rightarrow 5 \mathrm{CO}_{2(\mathrm{~g})}+6 \mathrm{H}_{2} \mathrm{O}_{(\mathrm{L})}
\end{aligned}
$$

Finally, the result shows that the steam production before turbo expander start-up is close to $144400 \mathrm{~kg} / \mathrm{h}$. As the lost steam production is 18320 $\mathrm{kg} / \mathrm{h}$, it represents a loss of $12.7 \%$. Hence, the refinery has to choose between losing this production and increasing the supplementary gas flow to compensate it.

\section{Estimation of Extra Supplementary Gas}

Equation (12) to Eq. (15) give PCI of supplementary gas (natural gas) equal to $47604 \mathrm{~kJ} / \mathrm{kg}$ $(11370 \mathrm{kcal} / \mathrm{kg}$ ) and Eq. (9) the lost sensible heat equal to $47.5 \mathrm{GJ} / \mathrm{h}$. Therefore, the Eq. (24) brings the conclusion that it is necessary plus $1330 \mathrm{~kg} / \mathrm{h}$ of extra natural gas to avoid losing the steam production of $18320 \mathrm{~kg} / \mathrm{h}$. As it was considered that the boiler was already fed with $1620 \mathrm{~kg} / \mathrm{h}$ of this supplementary gas to improve the combustion, the total amount of natural gas would increase to $2950 \mathrm{~kg} / \mathrm{h}$. The refinery should take into account this extra cost while planning the return on investment.

$\mathrm{W}_{\mathbf{G}}=\mathrm{Q}_{\text {loss }} /\left(\mathrm{PCI}_{\mathbf{S G}} * \eta_{\mathbf{B}}\right)$

\begin{tabular}{|c|c|}
\hline Calculated Variables & Result \\
\hline Outlet Expander Temperature $\left({ }^{\circ} \mathrm{C}\right)$ & 469 \\
\hline $\begin{array}{l}\text { Expander Power Output when To }= \\
643^{\circ} \mathrm{C} \text { and } \mathrm{Tf}=469^{\circ} \mathrm{C}(\mathrm{MW})\end{array}$ & 13.8 \\
\hline $\begin{array}{l}\text { Lost Sensible Heat in Upstream Boiler } \\
\text { After Expander Start-up (GJ/h) }\end{array}$ & 47.5 \\
\hline $\begin{array}{l}\text { Amount of Steam that would not be } \\
\text { Produced anymore due to Expander } \\
\text { Start-up }(\mathrm{kg} / \mathrm{h})\end{array}$ & 18320 \\
\hline $\begin{array}{l}\text { Inferior Calorific Power of Flue Gas } \\
\qquad(\mathrm{kJ} / \mathrm{kg})\end{array}$ & 565 \\
\hline $\begin{array}{c}\mathrm{Q}_{\text {Burn FG }}+\mathrm{Q}_{\text {Burn SG }}= \\
\text { Boiler Combustion Heat at Usual } \\
\text { Production }(\mathrm{GJ} / \mathrm{h})\end{array}$ & $\begin{array}{c}115.9+57.8 \\
=173.7\end{array}$ \\
\hline $\begin{array}{c}\mathrm{Q}_{\text {Sensible FG }}+\mathrm{Q}_{\text {Sensible SG }}^{+} \\
\mathrm{Q}_{\text {Sensible Air }}=\text { Boiler Sensible Heat at } \\
\text { Usual Production }(\mathrm{GJ} / \mathrm{h})\end{array}$ & $\begin{array}{c}200.4+0+ \\
0.3 \\
=200.7\end{array}$ \\
\hline $\begin{array}{l}\text { Total Boiler Heat at Usual Production } \\
\qquad(\mathrm{GJ} / \mathrm{h})\end{array}$ & 374.4 \\
\hline $\begin{array}{l}\text { Boiler Production Before Expander } \\
\text { Start-up }(\mathrm{kg} / \mathrm{h})\end{array}$ & 144400 \\
\hline $\begin{array}{l}\text { Inferior Calorific Power of } \\
\text { Supplementary Gas }(\mathrm{kJ} / \mathrm{kg})\end{array}$ & 47604 \\
\hline $\begin{array}{l}\text { Extra Supplementary Gas to keep } \\
\text { Usual Boiler Production }(\mathrm{kg} / \mathrm{h})\end{array}$ & 1330 \\
\hline
\end{tabular}

Table 4 and Fig. 4 resume the results:

Table 4. Process calculated variables.
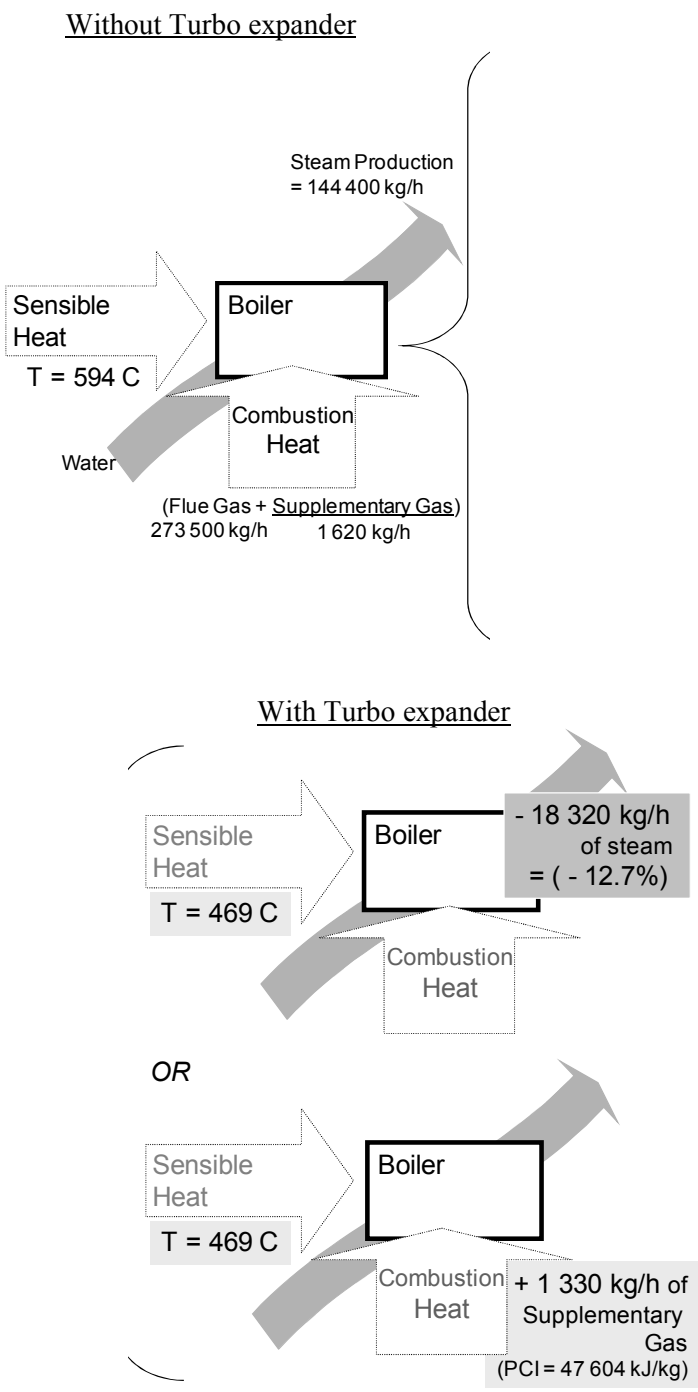

Figure 4. Impact of turbo expander on $\mathrm{CO}$ boiler.

\section{PREDICTING CONDENSATION}

Isolation valves allow expander rotating blades to stop instead of just turn slower, avoiding shutting down a FCC unit when its turbo expander needs maintenance. On the other hand, this improvement in the project implies that turbo expander and main duct will be cold just before start-up. Consequently, condensate may be found when the suction isolation valve is opened and hot gas comes into contact with the cold duct, what means that internals of the turbo expander are exposed to be severely damaged by condensate because of suddenly temperature change.

Moreover, partial combustion means that temperatures are not as high as in complete combustion process, but it means also that any leak represent a potential danger to operator's safety, since carbon monoxide is found in larger amount. Thus, it is not permitted to drain or vent the duct to atmosphere during start-up. 
Bringing together these two particularities reveals that it is needed to prevent expander from receiving condensate. So, it is necessary to project some drains connecting low points of upstream duct to orifice chamber downstream to guarantee that the start-up will be safe. After starting it up, the duct gets as hot as the flue gas and therefore the condensate problem is solved.

Figure 5 shows a prediction of condensate formation using flue gas mol fraction from Tab. 1. Establishing an operational pressure of $2.1 \times 10^{5} \mathrm{~Pa}$, it is possible to conclude that when flue gas comes into contact with the cold duct, the water condenses in ambient temperature.

In this case, condensation represents $34610 \mathrm{~kg} / \mathrm{h}$ or $9.6 \mathrm{~kg} / \mathrm{s}$ of liquid inside duct.

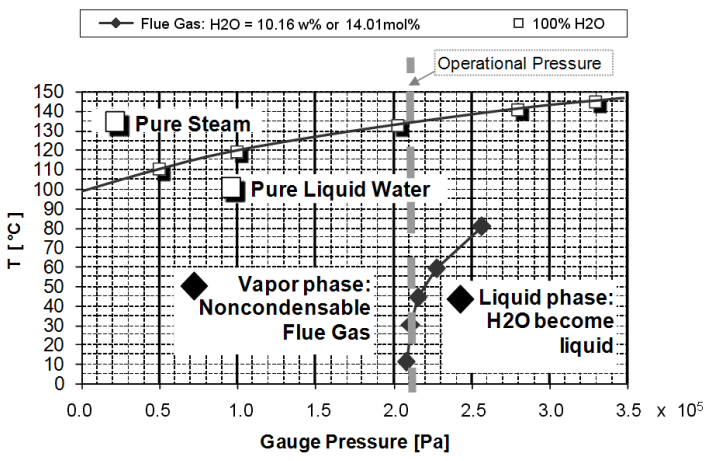

Figure 5. The limits between liquid and vapor phase inside duct.

To plot Fig. 5 for a range of temperatures, saturation moisture equations were used, when partial pressure is equal to saturation pressure. To compare with pure water, the values of pure water were plotted too, using Antoine's Equation.

$$
\begin{aligned}
& \mathrm{U}=\mathrm{m}_{\mathrm{H} 2 \mathrm{O}} / \mathrm{m}_{\mathrm{G}} \operatorname{seco} \\
& \text { Usat }=\mathrm{m}_{\mathrm{H} 2 \mathrm{O}} \mathrm{sat} / \mathrm{m}_{\mathrm{G}} \mathrm{seco} \\
& \mathrm{U}=\mathrm{Usat} \\
& \text { Usat }=\mathrm{M}_{\mathrm{H} 2 \mathrm{O}} / \mathrm{M}_{\mathrm{G}} \text { Seco } \\
& \text { *( } \left.\mathrm{P}_{\mathrm{H} 2 \mathrm{O}} \text { sat } /\left(\mathrm{P}_{\mathrm{abs}}-\mathrm{P}_{\mathrm{H} 2 \mathrm{O}} \text { Sat }\right)\right)
\end{aligned}
$$

$\mathrm{Us}=\mathrm{M}_{\mathbf{H} 2 \mathrm{O}} / \mathrm{M}_{\mathrm{G}} \operatorname{seco} *((\exp (\mathrm{AntA}-\mathrm{AntB} /(\mathrm{TK}+\mathrm{AntC})))$ $\left./\left(\mathrm{PmmHg} \mathrm{Abs}_{\mathrm{s}}-\exp (\mathrm{AntA}-\mathrm{AntB} /(\mathrm{TK}+\mathrm{AntC}))\right)\right)$

$\ln \left(\mathrm{P}_{\mathbf{H 2 O}}\right.$ sat $)=$ AntA-AntB $/(\mathrm{TK}+\mathrm{AntC})$ valid to $10.85^{\circ} \mathrm{C}<\mathrm{T}<167.85^{\circ} \mathrm{C}$

where:

$\begin{array}{ll}\mathrm{U} & \text { moisture } \\ \text { Usat } & \text { saturation moisture } \\ \mathrm{m}_{\mathrm{H} 2 \mathrm{O}} & \text { water mass, } \mathrm{kg} \\ \mathrm{m}_{\mathrm{G}} \mathrm{Seco} & \text { dry flue gas mass, } \mathrm{kg}\end{array}$

$\mathrm{m}_{\mathrm{H} 2 \mathrm{O}}$ sat water saturation mass, $\mathrm{kg}$

$\mathrm{M}_{\mathrm{H} 2 \mathrm{O}} \quad$ water molecular weight, $\mathrm{kg} / \mathrm{kmol}$

$\mathrm{M}_{\mathrm{G}}$ seco dry flue gas molecular weight, $\mathrm{kg} / \mathrm{kmol}$; (calculated excluding water from flue gas composition)

$\mathrm{P}_{\mathbf{H 2 O}}$ sat saturation water pressure, $\mathrm{mmHg}$

$\mathrm{P}_{\mathrm{abs}} \quad$ absolute pressure inside duct, $\mathrm{mmHg}$

TK temperature, $\mathrm{K}$

$\mathrm{PmmHg}_{\text {Abs }} \quad$ absolute pressure inside duct, $\mathrm{mmHg}$

AntA Antoine value $\mathrm{A}$ of property data bank = 18.3036

AntB Antoine value B of property data bank = 3816.44

AntC Antoine value $\mathrm{C}$ of property data bank = $-46.13$

\section{CLEANING DEVELOPMENT MECHANISM}

As turbo expander takes advantage of the energy that used to be wasted at orifice chamber, it is common to hear that its implementation is a cleaning development mechanism and consequently this improvement deserves certified carbon credits. However, carbon credits are regulated or distributed by an American organization, called "United Nations Framework Convention on Climate Change" (UNFCCC), which has written some rules about this issue.

The main rule is that the incorporated modification must be compared with the overall energetic system (electricity grid) from the country where it is implemented. This requirement means disadvantage to Brazilian industry to take carbon credits, because Brazilian power is mainly produced by hydroelectric plants, which does not pollute so much as Chinese coal plants, for instance. The criteria are based on $\mathrm{CO}_{2}$ emission. If new project emission is lower than the Brazilian baseline emission, then the difference is called Emission Reduction and gives carbon credits to the company which has implemented the project. It's worth remembering that, though they could be asked during project phase, carbon credits will be officially given to the company only after checking the results on site, during operational period.

Various projects can be employed to get carbon credits. About power recovery projects, it was found a methodology consulting the UNFCCC site (UNFCCC, 2008), which was simplified and applied to the studied case.

Considering that the turbo expander will produce 12.3 MW and the power recovery system itself will consume $0.3 \mathrm{MW}$ operating 24 hours a day, 365 days per year and there will be no leakage of $\mathrm{CO}_{2}$, the annual $\mathrm{CO}_{2}$ emission reduction is calculated following Eq. (31) to Eq. (36).

\section{Baseline Emission}

$\mathrm{BEh}=(\mathrm{Pw}-\mathrm{PwE})^{*} \mathrm{RV}$ 
$\mathrm{BEy}=\mathrm{BEh} * \mathrm{OF}$

where:

$\mathrm{BEh}$ baseline emission, $\mathrm{kgCO}_{2} / \mathrm{h}$; In this case: $(12.3-0.3) * 184.2=2210 \mathrm{kgCO}_{2} / \mathrm{h}$

BEy baseline emission, $\mathrm{kgCO}_{2} /$ year;

$\mathrm{Pw}$ expander power output, MW

PwE expander power consume, MW

RV reference value for Brazilian industry that remain fixed during the crediting period; $184.2\left(\mathrm{~kg} \mathrm{CO}_{2}\right) /(\mathrm{MW}$ produced $)$, according to UNFCCC (2008).

OF operational factor $=$ number of hours that the equipment really works during a year (excluding maintenance periods, for example); OF maximum would be 365 days/year * 24 hours/day $=8760$ hours/year

\section{Project Emission}

Regarding it is necessary $1330 \mathrm{~kg} / \mathrm{h}$ of extra supplementary gas, as estimated using Eq. (24), this is the flow that should be compared with baseline using Eq. (33) to Eq. (36).

$$
\begin{aligned}
& \text { PEhi }=\left[\left(\mathrm{W}_{\mathbf{S G}} * \mathrm{fi}\right) / \mathrm{Mi}\right] * \mathrm{n}_{\mathbf{C O} 2} * \mathrm{M}_{\mathbf{C O} 2} \\
& \mathrm{PEh}=\Sigma \text { PEhi } \\
& \text { PEy }=\text { Peh*OF }
\end{aligned}
$$

where:

PEhi project emission to each component "i" of the supplementary gas, $\mathrm{kgCO}_{2} / \mathrm{h}$

Peh project emission provoked by extra gas burning, $\mathrm{kgCO}_{2} / \mathrm{h}$

Pehy project emission provoked by extra gas burning, $\mathrm{kgCO}_{2} /$ year;

$\mathrm{W}_{\text {SG }}$ mass flow of extra gas, $(\mathrm{kg} \mathrm{SG}) / \mathrm{h}$

fi mass fraction, $(\mathrm{kg} \mathrm{i}) /(\mathrm{kg} \mathrm{SG})$

$\mathrm{Mi}$ “i” molecular weight $(\mathrm{kg} \mathrm{i} / \mathrm{kmol} \mathrm{i})$

$\mathrm{n}_{\mathrm{CO} 2}$ number of molecules of $\mathrm{CO}_{2}$ formed according to combustion equations, $(\mathrm{kmol} \mathrm{CO} 2) /(\mathrm{kmol} \mathrm{i})$; see Eq. (19) to Eq. (23).

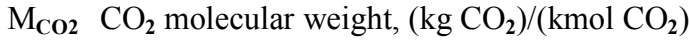

$\mathrm{OF}$ operational factor $=$ number of hours that the equipment really works during a year

\section{Emission Reduction}

Emission Reduction $=$ BEy $-\mathrm{PEy}$

Brazilian baseline calculated is equal to 2210 $\mathrm{kg} / \mathrm{h}$ of $\mathrm{CO}_{2}$ (Eq. (31)), while this new project emission represents $3560 \mathrm{~kg} / \mathrm{h}$ (Eq. (34)). Even before solving the next equations, it turns out that there is a negative result of $1350 \mathrm{~kg} / \mathrm{h}$. In conclusion, the hypothetical case does not fill the requirements for getting certified carbon credits or to be called a cleaning development mechanism, despite of all benefits that it would bring to the refinery and even to the country.

\section{REFERENCES}

API 520, 2000, Sizing, Selection, and Installation of Pressure-relieving Devices in Refineries Part I - Sizing and Selection, Seventh edition, American Petroleum Institute, p.42.

Brasil, N. I., 2004, Introdução à Engenharia Química. Rio de Janeiro: Interciência. pp. 277-282, 343-345. (in Portuguese)

Dziewulski, T. A., 1994, Tune-up Your FCCU Expander, Rotating Equipment, Hydrocarbon Processing, Aug 1994.

Smith, J. M., Van Ness, H. C., and Abbott, M. M., 2000, Introdução à Termodinâmica da Engenharia Química, $5^{\text {a }}$ ed., Rio de Janeiro: JC, pp. 104-105, 225, 577, 608. (in Portuguese)

UNFCCC, 2008, Project Design Document Form (CDM PDD) - Version 03, 15 Aug. 2008, $<$ http://cdm.unfccc.int/methodologies/index.html $>$.

Received: January 14, 2010 Revised: February 14, 2010 Accepted: March 14, 2010 